\title{
Glikogen Otot Rangka Ayam Broiler (Gallus gallus) setelah Pemberian Teh Kombucha dalam Air Minum
}

\author{
Nasrul Fathoni, M. Anwar Djaelani dan Sri Isdadiyanto, \\ Departemen Biologi Fakultas Sains dan Matematika \\ Universitas Diponegoro Semarang \\ toninasrul@yahoo.com,muhammadanwardajaelani@rocketmail.com,isdadiyanto@yahoo.com
}

\begin{abstract}
Kombucha tea beverage obtained by fermenting sweetened green tea for 12 days with Acetobacter xylinum and Saccharomyces which produce various kinds of organic acids, vitamins, and acts as a probiotic. The role of kombucha tea as a growth promoter is to that improve the metabolic process in the digestion of broiler chickens, so that nutrients can and fulfilled optimally for growth and development. The aim of this research was to analyze the sceletal muscle glycogen glycogen (Gallus gallus) after treat with kombucha tea in drinking water. Kombucha tea used is the result of fermentation of green tea for 12 days. This research used DOC chickens (Day Old Chicken) as much as 20 randomly divided into 4 treatments with concentration ie $0 \%, 10 \%, 20 \%$, and $40 \%$ kombucha tea in drinking water for 32 days. The variables measured were skeletal muscle glycogen levels, body weight, feed consumption and drink consumption. The data obtained were analyzed using ANOVA followed by Duncan Test with 95\% confidence level using SPSS 17.0 software. The results of this study showed that kombucha tea on skeletal muscle glycogen and feed consumption showed no significant difference, while on body weight and drink consumption showed significantly different results. Based on the results of the study, it can be concluded that giving kombucha tea in drinking water to a concentration of $40 \%$ has not been able to affect the skeletal muscle glycogen in broiler chickens.
\end{abstract}

Key words: Kombucha tea, broiler chicken, glycogen skeletal muscle

\begin{abstract}
Abstrak
Teh kombucha merupakan minuman hasil fermentasi teh dan gula oleh bakteri Acetobacter xylinum dan khamir Saccharomyces yang mengandung berbagai jenis asam organik dan vitamin, serta berperan sebagai probiotik. Peran teh kombucha sebagai growth promoter adalah untuk efisiensi penyerapan nutrisi secara sempurna dalam proses metabolisme pada pencernaan ayam broiler, sehingga nutrisi dapat terserap dan tercukupi secara optimal untuk pertumbuhan dan perkembangan. Tujuan penelitian ini adalah untuk menganalisis glikogen otot rangka ayam broiler (Gallus gallus) setelah pemberian teh kombucha dalam air minum. Teh kombucha yang digunakan merupakan hasil fermentasi teh hijau selama 12 hari. Penelitian ini menggunakan ayam broiler DOC (Day Old Chicken) sebanyak 20 ekor dibagi acak dalam 4 kelompok perlakuan dan 5 ulangan dengan konsentrasi yaitu, kelompok air minum dengan kombucha $0 \%$, kelompok air minum dengan kombucha 10\%, kelompok air minum dengan kombucha 20\%, dan kelompok air minum dengan kombucha $40 \%$ selama 32 hari. Variabel yang di ukur adalah kadar glikogen otot rangka, bobot tubuh, konsumsi pakan dan konsumsi minum. Data yang diperoleh dianalisis menggunakan ANOVA dilanjutkan dengan Uji Duncan dengan taraf kepercayaan 95\% dengan menggunakan perangkat lunak SPSS 17,0. Hasil Penelitian ini menunjukkan bahwa pemberian teh kombucha pada glikogen otot rangka dan konsumsi pakan menunjukkan hasil tidak berbeda nyata, sedangkan pada bobot tubuh dan konsumsi minum menunjukkan hasil berbeda nyata. Berdasarkan hasil penelitian, maka dapat disimpulkan bahwa pemberian teh kombucha dalam air minum sampai dengan konsentrasi $40 \%$ belum mampu mempengaruhi glikogen otot rangka ayam broiler.
\end{abstract}

Kata kunci : Teh kombucha, ayam broiler (Gallus gallus), glikogen otot rangka

\section{PENDAHULUAN}

Ayam ras pedaging disebut juga ayam broiler, merupakan jenis ras unggulan yang

Abidin (2002) menyatakan bahwa ayam ras pedaging merupakan hasil perkawinan silang. Sampai saat ini ayam pedaging dikenal masyarakat sebagai sumber protein hewani utama di Indonesia. Tahun 2011 dari total 2.554.200 ton produksi daging nasional, sebesar 52,4\% (1.337.900 ton) adalah daging ayam broiler (Tamalludin, 2014). memiliki produktivitas tinggi, terutama dalam memproduksi daging (Tamalludin, 2014).

Broiler atau ayam pedaging merupakan ternak yang paling ekonomis bila dibandingkan dengan ternak lain, kelebihan yang dimiliki adalah kecepatan pertambahan atau produksi daging dalam waktu yang relatif cepat dan singkat atau sekitar 4 - 5 minggu produksi daging sudah dapat dipasarkan atau dikonsumsi (Murtidjo, 2003). 
Glikogen merupakan sumber polisakarida utama pada sel hewan. Glikogen yang merupakan bentuk simpanan dari glukosa, terdapat hampir pada semua jaringan tubuh diantaranya otot. Jumlah glikogen berbeda dalam berbagai jaringan bergantung pada penyediaan glukosa dan kebutuhan energi. Kadar glikogen lebih banyak terdapat di hati (3-5\%) daripada di otot $(0,5-1 \%)$, tetapi jumlah glikogen seluruhnya lebih banyak di otot karena massa otot lebih banyak (Baynes, 2005). Glikogen adalah hasil akhir dari proses pemecahan glukosa dalam tubuh yang tersimpan dalam otot dan hati sebagai cadangan energi. Glukosa merupakan salah satu rangkaian bahan kimia dari karbohidrat atau zat pati yang telah melalui rangkaian proses metabolisme dalam tubuh sampai membentuk glukosa sebagai cadangan pati. Glukosa merupakan biomolekul yang penting dalam proses pembentukan energi untuk sel-sel di seluruh tubuh manusia secara keseluruhan (Arsana, 2016).

Tea-cider atau yang lebih dikenal dengan nama kombucha, merupakan produk minuman tradisional hasil fermentasi larutan teh dan gula yang memiliki cita rasa dan aroma yang khas, yaitu rasa asam-manis. Teh kombucha dikenal sebagai antioksidan yang mengandung polifenol, termasuk flavonoid. Salah satu flavonoid adalah derivatif katekin, senyawa ini merupakan antioksidan dengan kekuatan 100 kali lebih tinggi dari vitamin C dan 25 kali vitamin E (Adriani, 2011).

Peran teh kombucha dalam pencernaan ayam pedaging adalah untuk mengoptimalkan proses pencernaan, sehingga nutrien dapat diabsorbsi secara efektif oleh sel-sel absorbtif intestinum, diedarkan ke seluruh tubuh untuk mendukung proses pertumbuhan dan produktivitas. Hasil penelitian Ramli et al. (2007) menyatakan bahwa, pemberian tambahan kombucha dengan dosis $12,5 \%$ dalam air minum mampu meningkatkan pertumbuhan ayam pedaging dan secara ekonomis memperbaiki nilai konversi ransum (FCR), yang berarti setiap pakan yang dikonsumsi akan lebih efisien. Afsharmanesh dan Sadaghi (2014) menyatakan bahwa bobot tubuh, konsumsi pakan, dan kecernaan protein ayam pedaging meningkat setelah diberi pakan dengan tambahan teh kombucha sebanyak 20\%. Teh kombucha, selain memiliki keunikan sebagai pemacu pertumbuhan (growth promoter), juga berperan meningkatkan kualitas daging (Tana dan Djaelani, 2015).

Berdasarkan latar belakang di atas, maka perlu dilakukan penelitian mengenai glikogen otot rangka ayam broiler setelah pemberian teh kombucha pada air minum.

\section{METODE PENELITIAN}

Waktu dan Tempat Penelitian

Penelitian dilakukan pada bulan SeptemberOktober 2017 di Laboratorium Biologi Struktur dan Fungsi Hewan, Departemen Biologi, Fakultas Sains dan Matematika, Universitas Diponegoro

Alat dan Bahan

Alat yang digunakan pada penelitian ini, yaitu toples dengan volume $3 \mathrm{~L}$, kain kassa, tali, botol, kulkas, kandang pemeliharaan sebanyak 20 buah beserta perlengkapannya, timbangan analitik, gelas kaca, gelas beker, gelas ukur, termometer, $\mathrm{pH}$ ukur, timbangan digital, higrometer, papan parafin dan dissecting set.

Bahan yang digunakan pada penelitian ini, yaitu gula pasir, teh hijau, starter kombucha dengan jenis mikroorganisme Lactobacillus dan khamir Saccharomyces cerevisiae, 20 ekor ayam DOC (Day Old Chicken), pakan ayam BR II, air kran, vaksin (ND+IB) dan vitamin untuk ayam.

Cara Kerja

Penelitian ini menggunakan Rancangan Acak Lengkap (RAL). Hewan uji yang digunakan pada penelitian ini adalah ayam broiler DOC sebanyak 20 ekor. Ayam broiler tersebut dibagi dalam 4 perlakuan dengan 5 kali ulangan. Perlakuan diberikan berupa air minum atau larutan teh kombucha. Adapun 4 perlakuan tersebut adalah P0 yaitu kontrol, P1 yaitu (10\%), P2 yaitu (20\%) dan P3 yaitu (40\%). Variabel utama yang diukur adalah glikogen otot rangka. Data yang didapat diuji dengan ANOVA, bila uji ANOVA menunjukkan adanya perbedaan antar kelompok perlakuan maka diuji lanjut menggunakan uji Duncan dengan taraf kepercayaan 95\%. Data dianalisis menggunakan program komputer SPSS (Statistikal Product and Services Solution) versi 17.0 (Santoso, 2008).

\section{HASIL DAN PEMBAHASAN}

Data hasil penelitian yang meliputi variabel utama, yaitu glikogen otot rangka dan variabel pendukung, antara lain bobot tubuh, konsumsi pakan dan konsumsi air minum ayam broiler setelah pemberian teh kombucha pada air minum 
Tabel 1. Hasil analisis statistik rata-rata glikogen otot rangka, bobot tubuh, konsumsi pakan dan konsumsi air minum ayam broiler (Gallus gallus) setelah pemberian teh kombucha.

\begin{tabular}{ccccc}
\hline Variabel & $\begin{array}{c}\text { Glikogen } \\
\text { Otot } \\
\text { Rangka }\end{array}$ & $\begin{array}{c}\text { Bobot } \\
\text { Tubuh }\end{array}$ & $\begin{array}{c}\text { Konsumsi } \\
\text { Pakan }\end{array}$ & $\begin{array}{c}\text { Konsumsi } \\
\text { Minum }\end{array}$ \\
\hline Kontrol & $5,85^{\mathrm{a}}$ & $1318^{\mathrm{a}}$ & $3160^{\mathrm{a}}$ & $6119,80^{\mathrm{a}}$ \\
$10 \%$ & $6,20^{\mathrm{a}}$ & $1240^{\mathrm{ab}}$ & $3322^{\mathrm{a}}$ & $5386,80^{\mathrm{b}}$ \\
$20 \%$ & $6,11^{\mathrm{a}}$ & $1175^{\mathrm{ab}}$ & $3640^{\mathrm{a}}$ & $5452,50^{\mathrm{b}}$ \\
$40 \%$ & $7,16^{\mathrm{a}}$ & $1076^{\mathrm{b}}$ & $2984^{\mathrm{a}}$ & $4860,60^{\mathrm{c}}$ \\
\hline
\end{tabular}

Keterangan : Superskrip yang berbeda pada baris yang sama menunjukkan perbedaan yang nyata antar perlakuan. $P O=$ kontrol, $P 1=10 \%, P 2=20 \%, P 3=40 \%$

\section{Glikogen Otot Rangka}

Hasil analisis ANOVA (Analysis of Variance) pada taraf signifikansi 5\% menunjukkan bahwa teh kombucha tidak memberi pengaruh nyata terhadap kadar glikogen otot antara P0, P1, P2 dan P3 (Tabel 4.1). Glikogen otot yang diukur ialah bagian otot rangka femuralis. Bagian ini merupakan bagian otot yang peka terhadap nutrisi (Yaman, 2008). Rata-rata kadar glikogen otot rangka femularis ayam broiler pada kelompok perlakuan P0 adalah 5,85\% P1 6,20\%, P2 6,11 dan P3 7,16\%. Hasil penelitian ini membuktikan bahwa pemberian teh kombucha dengan konsentrasi 10\%, 20\% dan $40 \%$ tidak memberi pengaruh nyata terhadap kadar glikogen otot rangka pada ayam broiler. Penelitian ini mengindikasikan bahwa pemberian teh kombucha dengan kisaran konsentrasi tersebut tidak berpengaruh terhadap kadar glikogen otot rangka femularis pada ayam broiler.

Hasil penelitian ini diduga karena adanya bakteri dan jamur saat fermentasi, yang mengubah kandungan gula menjadi beberapa jenis asam dan kandungan lainnya, sehingga kandungan gula yang ada pada teh kombucha saat fermentasi berkurang. Penelitian ini sesuai dengan pendapat Naland (2004) yang menyatakan bahwa kultur teh kombucha merupakan kumpulan dari bakteri dan beberapa jenis jamur yang membentuk substansi gelatinoid yang tumbuh mengikuti wadahnya dan menghasilkan enzim yang dapat mengubah kandungan gula menjadi berbagai jenis asam, vitamin dan senyawa alkohol yang berkhasiat.

\section{Bobot Tubuh}

Hasil analisis ANOVA (Analysis of Variance) pada taraf signifikansi 5\% menunjukkan bahwa bobot tubuh ayam broiler antara P0, P1 dan P2 tidak memberi pengaruh nyata, sedangkan antara P0 dengan P3 menunjukkan bahwa teh kombucha memberi pengaruh nyata (Tabel 4.1). Hasil rerata bobot tubuh ayam broiler (Gallus gallus) (\%) dapat dilihat pada Gambar 1

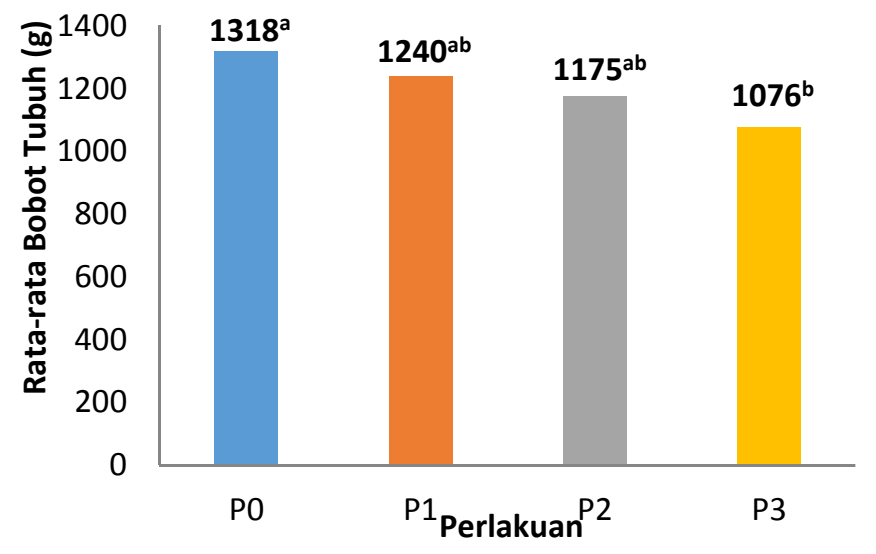

Gambar 1 Histogram rata-rata bobot tubuh ayam broiler (Gallus gallus) setelah perlakuan (g) Keterangan : $P 0=$ kontrol, $P 1=10 \%$, $P 2=20 \%, P 3=40 \%$

Hasil penelitian menunjukkan bahwa bobot tubuh ayam broiler tidak memberi pengaruh nyata antara P0, P1 dan P2 (Tabel 4.1). Hasil penelitian ini diduga karena ada varaibel lain yang memberi pengaruh dominan terhadap bobot tubuh selain perlakuan, seperti ketersediaan protein dalam pakan. Khumaini dkk. (2012) menyatakan pakan dengan kandungan protein 21-23\% memberi pengaruh terhadap bobot tubuh ayam broiler yang tidak berbeda nyata. Penelitian ini disebabkan protein dengan kandungan tersebut memberi pengaruh dominan terhadap pertumbuhan ayam broiler, khususnya pada masa starter dan grower. Kondisi ini akhirnya berpengaruh pada bobot tubuh ayam broiler yang tidak berbeda nyata antara $\mathrm{P} 0$ dengan P1 dan P2.

Teh kombucha mengandung asam-asam organik yang berperan sebagai acidifier, menciptakan suasana asam pada saluran pencernaan yang bertujuan untuk meningkatkan efisiensi penyerapan nutrien, namun kondisi yang terlalu asam diduga dapat menghambat kinerja enzim yang optimal pada suasana basa. Campbell et al. (2002) menyatakan bahwa aktivitas enzim dipengaruhi oleh beberapa faktor diantaranya, suhu, $\mathrm{pH}$, konsentrasi substrat, serta keberadaan aktivator dan inhibitornya. Suhara (2010) menyatakan bahwa enzim peka terhadap perubahan $\mathrm{pH}$ dan memiliki suasana $\mathrm{pH}$ optimalnya masing-masing. Penghambatan kinerja enzim sebagai katalisator akibat suasana $\mathrm{pH}$ yang tidak sesuai beresiko menurunkan absorbsi nutrien yang dibutuhkan untuk keperluan pertumbuhan dan pembentukan 
jaringan tubuh sehingga berdampak pada penurunan bobot tubuh ayam broiler. Lebih lanjut dinyatakan, $\mathrm{pH}$ darah yang terlalu asam berakibat terhadap penurunan afinitas $\mathrm{Hb}$ dalam mengikat oksigen yang pada akhirnya akan terjadi penurunan metabolisme dan energi yang dihasilkan. Energi yang rendah berakibat pada penurunan produktivitas yang tercermin pada penurunan bobot tubuh.

\section{Konsumsi Pakan}

Hasil analisis ANOVA (Analysis of Variance) pada taraf signifikansi 5\% menunjukkan bahwa konsumsi pakan ayam broiler tidak berbeda nyata antara kontrol (P0) dengan perlakuan lainnya yaitu P1, P2 dan P3 (Tabel 4.1). Hal ini menunjukkan bahwa pemberian teh kombucha dalam air minum tidak mempengaruhi konsumsi pakan pada ayam broiler. Rata-rata konsumsi pakan kumulatif ayam broiler selama 39 hari pemeliharaan ialah 3277 g/ekor. sesuai dengan standar kebutuhan pakan ayam broiler betina kisaran umur 35-42 hari yaitu 3147-4438 g/ekor (Aviagen 2014).

Konsumsi pakan yang tidak berbeda nyata antar perlakuan berarti bahwa setiap ayam broiler memiliki palatabilitas yang sama, sehingga pakan yang dikonsumsi relatif sama. Kesatria (2016) menyatakan palatabilitas adalah salah satu faktor yang mempengaruhi konsumsi pakan, palatabilitas tersebut bergantung pada beberapa hal, yaitu penampilan dan bentuk pakan, bau, rasa, tekstur, dan suhu lingkungan.

Konsumsi Minum

Hasil analisis ANOVA (Analysis of Variance) pada taraf signifikansi 5\% menunjukkan bahwa konsumsi air minum ayam broiler menunjukkan perbedaan yang nyata pada kelompok perlakuan teh kombucha konsentrasi 10\%, 20\%, dan $40 \%$ terhadap kontrol. (Tabel 1). Hasil rerata konsumsi air minum ayam broiler (Gallus gallus) dapat dilihat pada Gambar .2

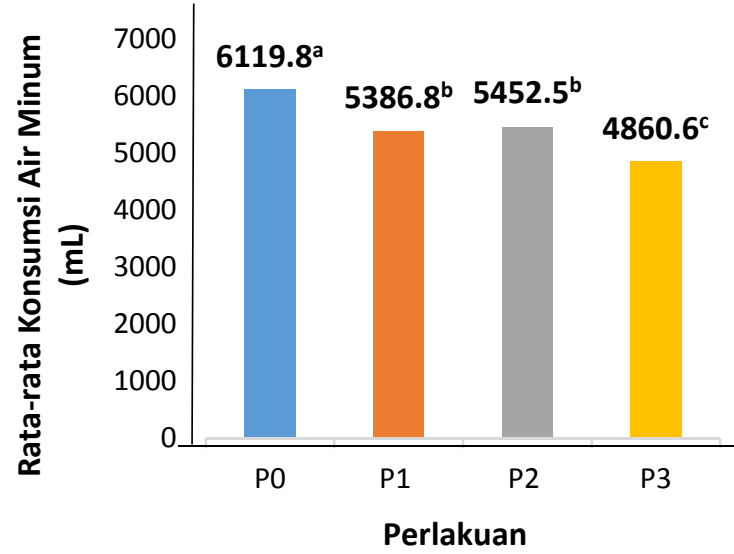

Gambar 2 Histogram rata-rata konsumsi air minum ayam broiler (Gallus gallus) setelah perlakuan $(g)$ Keterangan : PO = kontrol, tanpa tambahan teh kombucha, $P 1=$ air minum $+10 \%$ teh kombucha, $P 2=$ air minum $+20 \%$ teh kombucha, $P 3=$ air minum $+40 \%$ teh kombucha.

Hasil penelitian ini menunjukkan bahwa peningkatan konsentrasi teh kombucha dalam air minum memberi pengaruh terhadap penurunan konsumsi air minum ayam broiler. Penurunan konsumsi air minum diduga akibat rasa asam dan kandungan tanin pada teh kombucha. Keasaman $(\mathrm{pH})$ awal fermentasi teh kombucha dengan teh hijau adalah 5,6 dan akan menurun hingga dibawah 2,6 pada hari ke-12 fermentasi (Ardheniati, 2008). Rasa memberikan dampak besar terhadap konsumsi air minum pada broiler (Tabler et al., 2012). Kandungan tanin dalam teh kombucha memiliki daya cerna dan palatabilitas yang rendah karena interaksi tanin dengan protein dalam ludah (saliva) dan glikoprotein dalam mulut menyebabkan rasa sepat dalam mulut (Widodo, 2002). Konsumsi air minum terendah terdapat pada perlakuan $\mathrm{P} 3$, yaitu rata-rata 4860,60 mL/hari (Gambar 4.2).

Konsumsi air minum pada ayam broiler dengan konsentrasi 10\%, 20\% dan 40\% terhadap kontrol menunjukkan perbedaan yang nyata. Hal ini diduga akibat adanya rasa asam dalam teh kombucha. Semakin tinggi konsentrasi teh kombucha semakin banyak kandungan asam-asam organik sehingga berpengaruh terhadap penurunan palatabilitas konsumsi air minum ayam broiler (Tana dan Djaelani, 2015). Palatabilitas merupakan faktor yang sangat penting untuk menentukan tingkat konsumsi air minum pada ayam (Parakkasi, 1990). Palatabilitas ditentukan oleh sistem perasa gustative of taste buds ayam yang berada pada bagian belakang atap rongga mulut dan pada lidah (Tabler, 2012), dan dipengaruhi oleh rasa, tekstur, bau, dan akibat yang dirasakan setelah 
mengonsumsi air minum (Amrullah, 2004). Hasil penelitian ini membuktikan bahwa konsentrasi teh kombucha yang tinggi dapat menggangu sistem perasa pada ayam broiler yang berakibat pada penurunan palatabilitas dan air minum yang dikonsumsi. Konsumsi air minum ayam broiler yang menurun merupakan bentuk adaptasi fisiologis untuk menyeimbangkan energi dalam tubuh (Amrullah, 2004). Air minum yang banyak mengandung sumber energi akan dikonsumsi lebih sedikit dibanding air minum yang mengandung sumber energi lebih rendah. Hasil penelitian ini sesuai dengan penelitian yang dilakukn. Hasil penelitian Akhadiarto (2005) menunjukkan, ayam broiler yang diberi air minum dengan kandungan energi yang tinggi atau bervariasi, lebih sedikit mengonsumsi air minum dibandingkan dengan kandungan energi yang lebih rendah.

Hasil analisa statistik pada Tabel 4.1, baik variabel utama atau pendukung menunjukkan bahwa pemberian teh kombucha dalam air minum dengan konsentrasi $40 \%$ mampu menurunkan konsumsi air minum ayam broiler pada perlakuan P3 berbeda nyata dengan kontrol. Penurunan konsumsi air minum ini diikuti penurunan bobot tubuh ayam broiler, namun tidak diikuti peningkatan konsumsi pakan dan glikogen otot rangka. Ayam broiler pada perlakuan P3 setelah pemberian teh kombucha dengan konsentrasi $40 \%$ memiliki rata-rata konsumsi air minum terendah, yaitu 4860,60 $\mathrm{mL} /$ hari dengan bobot tubuh akhir $1076 \mathrm{~g}$ yang merupakan bobot terendah. Bukti konsumsi air minum ayam broiler pada penelitian ini lebih rendah dibanding hasil penelitian Suprijatna (2005) yang menyatakan bahwa konsumsi air minum ayam broiler sebanyak $6514,74 \mathrm{~mL} /$ hari. Hasil penelitian ini menunjukkan bahwa konsumsi air minum ayam broiler berada dibawah rata-rata konsumsi yang seharusnya, sehingga beresiko mengganggu proses metabolisme dalam tubuh. Lacy (2002) menyatakan bahwa air berperan penting dalam reaksi metabolisme, memelihara temperatur tubuh, pencernaan makanan, dan pembuangan limbah, sehingga kekurangan air akan menghambat pertumbuhan dan perkembangan ayam broiler. Terhambatnya pertumbuhan dan perkembangan akan berpengaruh terhadap penurunan bobot tubuh seperti bukti pada penelitian ini, dimana ayam broiler pada perlakuan P3 memiliki rata-rata bobot tubuh akhir 1076 g/ekor yang berbeda nyata dengan kontrol.

Rasyaf (2008) menyatakan bahwa bobot tubuh ayam broiler dipengaruhi oleh kualitas dan kuantitas pakan yang dikonsumsi, sehingga kandungan nilai gizi yang seimbang diperlukan untuk pertumbuhan yang optimal. Ardana (2009) menyatakan bahwa air minum merupakan nutrien yang esensial pada ayam broiler, tidak hanya berfungsi sebagai nutrien, tetapi air juga merupakan komponen utama darah sebagai alat transportasi dalam tubuh ayam broiler, berfungsi untuk memperlunak pakan, membantu dalam proses pencernaan dan penyerapan nutrien lainnya serta sebagai penyeimbang dalam tubuh. Konsumsi pakan yang sama namun konsumsi air minum yang berbeda seperti hasil penelitian ini akan berpengaruh terhadap hambatan dalam proses pencernaan, penyerapan, penurunan metabolisme produk energi, pertumbuhan dan perkembangan sehingga pada akhirnya akan mempengaruhi penurunan bobot tubuh ayam broiler.

\section{KESIMPULAN}

Kesimpulan pada penelitian ini pemberian teh kombucha dalam air minum sampai konsentrasi $40 \%$ belum mampu mempengaruhi glikogen otot rangka pada ayam broiler.

\section{UCAPAN TERIMAKASIH}

Ucapan terima kasih disampaikan kepada staff Laboratorium Biologi Struktur dan Fungsi Hewan, Departemen Biologi, Fakultas Sains dan Matematika, Universitas Diponegoro. Semarang yang telah membantu dalam pelaksanaan penelitian.

\section{DAFTAR PUSTAKA}

Abidin, Z. 2002. Meningkatkan Produktivitas Ayam Ras Pedaging. Agromedia Pustaka, Jakarta.

Abidin, T. dan M.Z. Hutagalung. 2010. Pengaruh Teh Kombucha Terhadap Kekerasan Enamel. Dentika Dental Journal, 15(1) : 67-70.

Adriani, L., H.S. Mainah and N. Marbun. 2011. The Effect of Suplementation Fermented Kombucha Tea on Fat and Cholesterol Levels od Duck Meat. Lucrări Ştiin ifice Seria Zootehnie, (55) : 103-105.

Brady, L. J., D.D. Gallaher and F. Busta. 2000. The Role of Probiotic Cultures in The Prevention of Colon Cancer. J. Nutr, $130: 410 S$ - 414S.

Cahyono. 2005. Pertumbuhan dan Perkembangan Ayam Broiler pada Fase Post Natal. Penerbit Swasta Nulus, Denpasar.

Campbell, N.A., J.B. Reece and L.G. Mitchell. 2002. Biologi Ed. Kelima - Jilid 1. Alih bahasa: Rahayu Lestari. Erlangga, Jakarta.

Chen, C. and B. Y. Liu. 2000. Changes in major components of tea fungus metabolites during 
prolonged fermentation. J Appl Microbiol, 89 : 834-9.

Gauthier, R. 2002. Intestinal Health, The Key to Productivity (The Case of Organic Acid). XXVII Convencion ANECA-WPDC. Puerto Vallarta, Jal.Mexico.

Ghazalah, A. A., A.M. Atta, K. Elkloub, M.E.L. Moustafa and R.F.H. Shata. 2011. Effect of dietary supplementation of organic acids on performance, nutrients digestibility and health of broiler chicks. International Journal of Poultry Science, (10) : 176-184.

Hardjosworo dan Rukminasih. 2000. Peningkatan Produksi Ternak Unggas. Penebar Swadaya, Jakarta.

Heri, S. 2015. Acidifier Permudah Fungsi Alat Pencernaan. www.trobos.com. 9 Januari 2016.

Kartadisastra, M. R. 2004. Pengelolaan Pakan Ayam. Kanisius, Yogyakarta.

Kartasudjana, R dan E. Suprijatna. 2006. Manajemen Ternak Unggas. Penebar Swadaya, Jakarta.

Kaufmann, K. 2013. Kombucha Rediscovered : The Medical Benefits of an Ancient Healing Tea. Books Alive, USA.

Kesatria, H. Nur dan B. Malik. 2016. Pengaruh Substitusi Pakan Komersil dengan Tepung Ampas Kelapa Terhadap Performa Ayam Kampung. Jurnal Peternakan Nusantara, 2(1) : 45-46.

Khumaini, A., R.E. Mudawaroch and D.A. Hanung. 2012. Pengaruh Penambahan Teh Kombucha dalam Air Minum Terhadap Konsumsi Pakan dan Konsumsi Air Minum Ayam Broiler. Surya Agritama,. 1(2) : 85-93.

Kompiang, I.P. 2009. Pemanfaatan Mikroorganisme Sebagai Probiotik untuk Meningkatkan Produksi Ternak Unggas di Indonesia. Pengembangan Inovasi Pertanian, 2(3) : 177-191.

Koolman, J. 2001. Atlas berwarna dan Teks Biokimia. Hipokrates, Jakarta.

Kusnandar, N. 2004. Kandungan Kolesterol Daging, Lemak Abdominal, dan Presentase Organ Dalam Ayam Broiler yang Diberi Minum Teh Fermentasi Kombucha pada Waktu yang Berbeda. Skripsi. Program Studi Nutrien dan Makanan Ternak. Institut Pertanian Bogor, Bogor.

Lacy, M. 2002. Broiler Management.: Commercial Chicken Meat and Egg Production. Kluwer Academic Pub. Norwell, MA.

Markov, S.L., R.V. Malbasa, M.J. Hauk, and D. Cvetkovic. 2001. Investigation of Tea Fungus
Microbe Associations. The Yeasts. Acta Period Technol, 32 : 133-8.

Marks, D.B., A.D. Marks dan C.M. Smith. 2000. Biokimia Kedokteran Dasar. Edisi Ke-1. Penerbit ECG. Jakarta..

Mayes, P.A. 2003. Metabolisme glikogen. DI dalam: Murray RK, Granner DK, Mayes PA, Rodwell VW. Biokimia Harper's Edisi 25. Penerjemah: Hartono A. Penerbit EGC, Hlm:187 194. Terjemahan dari Harper's Biochemistry.

Murray, dan K. Robert. 2009. Biokimia Harper. Buku Kedokteran, Jakarta.

Marsh, A.J., O. Sullivan, C. Hill, R.P. Ross and P. Cotter. 2014. Sequence-based Analysis of The Bacterial and Fungal Compositions of Multiple Kombucha (Tea Fungus) Samples. Food Microbiol, 38 : 171-8.

Murtidjo, B. A. 2003. Pedoman Beternak Ayam Broiler. Kanisius, Yogyakarta.

Naland, H. 2004. Kombucha : Teh Ajaib Pencegah dan Penyembuh Aneka Penyakit. Agromedia Pustaka, Jakarta.

Soeparno. 2011. Ilmu Nutrisi dan Gizi Daging. Gadjah Mada University Press, Yogyakarta.

Suhara. 2010. Dasar-dasar Biokimia. Prisma Press, Bandung.

Suharyanto. 2009. Metabolic Responses on Transport Stress and the Effect on Meat Characteristics (A Review), Jurnal Sain Peternakan Indonesia, 2(1) : 35-38.

Suprijatna, E. 2005. Ilmu Dasar Ternak Unggas. Penebar Swadaya, Jakarta.

Sutandio, A. 2011. Membuat Teh Kombucha. http://indokombucha.com/cara-membuatteh-kombucha/. 23 Mei 2016.

Tabler, T., W. Jessica and Z. Wei. 2012. WaterRelated Factors in Broiler Production. Mississippi State University Extension Service.

Tamalludin, F. 2014. Panduan Lengkap Ayam Broiler. Penebar Swadaya, Jakarta.

Tana, S dan M.A. Djaelani. 2015. Kadar Kolesterol Daging Ayam Broiler setelah Pemberian Teh Kombucha. Buletin Anatomi dan Fisiologi, 23(1) : 1-8.

Vali, F. 2008. Poultry Science (Animal Agricultural Series). 3th Edition. Instate Publisher, Inc. Danville, Illiones.

Wahyu, J. 2004. Ilmu Nutrisi Unggas. Gadjah Mada University Press, Yogyakarta.

Widodo, W. 2002. Nutrisi dan Pakan Unggas Kontekstual. Universitas Muhammadiyah Malang, Malang. 
Nasrul Fathoni, M. Anwar Djaelani dan Sri Isdadiyanto

Yaman, A. 2008. Ayam Kampung Unggul. PT Niaga Swadaya, Jakarta.

Yuwanta, T. 2004. Dasar Ternak Unggas. Kanisius, Yogyakarta. 